\title{
EFFECT OF TREE SPACING ON GROWTH AND FRUIT PRODUCTION OF SOME NEW CITRUS CULTIVARS IN EGYPT
}

(Received: 4. 11. 2008)

\author{
By \\ M.A. Bassal \\ Department of Horticulture, Faculty of Agriculture, Suez Canal University, 41522 Ismailia, Egypt
}

\begin{abstract}
'Hernandina' clementine, 'Clemenules' clementine and 'Nova' mandarin budded on sour orange rootstock were produced in a screenhouse and planted in the field under drip irrigation system during October 1999 in a private orchard at "Wady El-Mullak" region, Ismailia Governorate (Latitude, 30³6' N; longitude, 32 $14^{\circ} \mathrm{E}$; Altitude, $10 \mathrm{~m}$ above sea level), which is one of the largest citrus production region in Egypt. All cultivars were planted at $2 \times 5 \mathrm{~m}$ and $5 \times 5 \mathrm{~m}$. Annual fruit production, cumulative and average yields per tree and per feddan were estimated during five seasons, starting from $3^{\text {rd }}$ year after planting (YAP) to $7^{\text {th }}$ YAP (2006/2007). Tree height, canopy diameter and circumference, tree volume, and trunk girth were determined in the $6^{\text {th }}$ and $7^{\text {th }}$ YAP.

Trees planted at $2 \times 5 \mathrm{~m}$ were the tallest, but the canopy diameter and circumference, and volume of trees planted at $5 \times 5 \mathrm{~m}$ were the largest. On the other hand, trees of 'Nova' mandarin had the lowest canopy diameter and circumference, while 'Clemenules' clementine trees had more height and volume.

Initial yields per tree $\left(3^{\text {rd }}\right.$ and $\left.4^{\text {th }} \mathrm{YAP}\right)$ from planting spacing of $2 \times 5 \mathrm{~m}$ were higher than those from the wide spacing, but starting from $5^{\text {th }}$ to $7^{\text {th }}$ YAP the situation was inverted. Cumulative yield for the first 5 years of production and the average annual yield per tree revealed the superiority of the wide spacing. On the contrary, the yield per feddan $\left(4200 \mathrm{~m}^{2}\right)$ from trees planted at $2 \times 5 \mathrm{~m}$ was about $454 \%, 221 \%$, $137 \%, 76 \%$ and $90 \%$ greater than those planted at $5 \times 5 \mathrm{~m}$ in the $3^{\text {rd }}, 4^{\text {th }}, 5^{\text {th }}, 6^{\text {th }}$ and $7^{\text {th }}$ YAP, respectively. Cumulative yield per feddan from closely planted trees was $40 \mathrm{t}(117 \%)$ more than from widely spaced.

'Hernandina' clementine produced more yields in the $3^{\text {rd }}$ and $4^{\text {th }}$ YAP compared with other cultivars; while 'Clemenules' clementine was the highest in the $5^{\text {th }}$ YAP. 'Nova' mandarin produced the highest yield in the $7^{\text {th }}$ YAP, while in $6^{\text {th }}$ one were statistically similar to those of 'Hernandina', which produced the highest yield. Cumulative and average annual yield per tree indicated that 'Hernandina' and 'Nova' cultivars were more productive than 'Clemenules' under the conditions of this study. On the other hand, 'Clemenules', 'Hernandina' and 'Nova', as new citrus cultivars in Egypt performed satisfactory in a highdensity planting $(2 \times 5 \mathrm{~m})$ through 7 year after planting, despite of 'Nova' mandarin was the most excellent, followed by 'Hernandina' and 'Clemenules' (cumulative yields were 82, 71 and $68 \mathrm{t} /$ feddan, for the three cultivars, respectively); and could continue until the productivity per feddan decrease compared to normal spacing.
\end{abstract}

Key words: citrus, clementine, cultivars, planting density, tree growth tree spacing, yields,.

\section{INTRODUCTION}

Citrus production must provide a rapid recovery of investment capital in order to provide maximum average net returns. Generally, closelyplanted groves provide greater and earlier returns, and better management (Tucker et al., 1994 and Wheaton et al., 1995b). By facilitating more efficient fertilizer uptake from root systems and better spray interception of crop protection chemicals by tree canopies, higher density plantings provide earlier returns on investment and can help reduce energy use. One advantage of closely spaced and hedgerow systems is that they develop bearing volume more rapidly (Parsons and Wheaton, 2006).

Xian et al. (1994) reported that the ideal planting density is 2250 - 3000 trees/ha for 'Ponggan' mandarin; while Wheaton et al. (1995a) recommended planting densities of 350 to 1000 trees/ha for oranges in Florida. Furthermore, QingSheng and ShinXian (2002) suggested planting density not less than 1995 trees/ha for 
'Washington Navel' orange. However, Nasir et al. (2006) found that planting density of $7.0 \times 7.0 \mathrm{~m}$ for grapefruit performed better, while the planting distance of $3.5 \times 3.5 \mathrm{~m}$ ranked last.

Yield of 'Hamlin' and 'Valencia' oranges was increased with increasing tree density (370-889 trees/ha) during the early years of production, while for tree ages 9 to 13 years there was no consistent relationship between yield and tree density (Wheaton et al., 1995a). During the first 8 years, tree vigor was unimportant and production increased as tree density increased (150 - 360 trees/acre) for 'Hamlin' and 'Valencia' oranges. Trees of low vigor never fill their allocated space and thus never generate maximum economic returns if planted at wide spacing (Wheaton et al., 1995b).

Tree spacing must reflect the tree vigor of a particular variety and rootstock combination as well as site, environment, and management (Wheaton et al., 1995b). Because of the lack of research information about the performance of citrus trees in a high density planting under the Egyptian conditions, the present study was undertaken to compare the effect of two tree spacing on the growth and yield of 'Clemenules' and 'Hernandina' clementine's and 'Nova' mandarin as newly introduced cultivars to Egypt (Bassal, 2001), budded on sour orange as the common rootstock, in an attempt to fill allotted tree space quicker and to obtain economic yields earlier in the lifespan of the orchard.

\section{MATERIALS AND METHODS}

Trees of three new clementine and mandarin hybrid cultivars namely: 'Hernandina' (Citrus clementina Hort. ex Tan.), 'Clemenules' ( $C$. clementina Hort. ex Tan.) and 'Nova' mandarin $[C$. clementina Hort. ex Tan. x Orlando Tangelo $(C$. reticulata Blanco $x$ C. paradisi Macf.)], budded on sour orange rootstock were produced in a screenhouse as previously described by Bassal (2009).

Uniform 1-year-old trees of each cultivar were planted in the field (sandy soil) under drip irrigation system during October 1999 in a 3 feddans site of a private orchard at 'Wady ElMullak' region, Ismailia Governorate (Latitude, $30^{\circ} 36^{\prime} \mathrm{N}$; longitude, $32^{\circ} 14^{\prime} \mathrm{E}$; Altitude, $10 \mathrm{~m}$ above sea level), which is one of the largest citrus production region in Egypt. All cultivars were planted at two spacing; i.e., $2 \times 5 \mathrm{~m}$ and $5 \times 5 \mathrm{~m}$, providing tree densities of 400 and 160 trees per feddan, respectively. Field plots were two rows $\mathrm{x}$ forty five trees with the center twelve trees (two rows $\mathrm{x}$ six trees) per each cultivar in every planting density chosen and labeled for data collection. The experiment was arranged in a randomized complete blocks design with fourtrees/plot and three replicates (Steel et al., 1997).

Trees were planted in north-south rows as part of a commercial grove. A regular commercial young tree care program was followed for the first 2 years, which included fertilizing on an individual tree basis. Beginning with year 3, fertilizer and foliar pesticides were applied uniformly on a land area basis. Thus, trees at different spacing all received water, fertilizer, and pest management on a land area basis, not on a per tree basis. Fertilizer was applied at recommended rates by Egyptian Ministry of Agriculture. Regular annual light manual pruning after fruit harvesting was begun in the $3^{\text {rd }}$ year after planting (YAP) to maintain the tree natural shape and facilitate the light penetration.

In February of $6^{\text {th }}$ and $7^{\text {th }}$ YAP $(2005 / 2006$ and 2006/2007), tree height, canopy diameter in the two tree directions (to obtain the average diameter), canopy circumference, trunk girth at 15 $\mathrm{cm}$ above the budding union, were measured. The canopy volume $\left(\mathrm{m}^{3}\right)$ was calculated according to Wutscher (1995) as follows.

Tree volume $=\left(\right.$ Tree diameter ${ }^{2} \mathrm{x}$ Tree height $) / 4$

In each season, starting from $3^{\text {rd }}$ YAP (2002/2003) to $7^{\text {th }}$ YAP $(2006 / 2007)$, at harvest time, the weight of harvested fruits per tree was recorded. The annual fruit productions, cumulative and average yields per tree and per feddan were estimated during five seasons.

Statistical analysis: The experimental design was randomized complete blocks with a splitblock experiment (Steel et al., 1997). Analysis of variance, with tree spacing as the main plot and cultivar as the subplot, and means comparison (LSD, $P<0.05$ ) were performed using MSTAT-C statistical package (M-STAT, 1990).

\section{RESULTS AND DISCUSSION \\ 3.1- Vegetative growth \\ 3.1.1. Canopy diameter and circumference:}

Cultivars were statistically different, whereas trees of 'Nova' mandarin had the lowest canopy diameter and circumference as compared with those of 'Hernandina' and 'Clemenules' clementine's in the $6^{\text {th }}$ and $7^{\text {th }}$ YAP, despite of the data of tree circumference in the $7^{\text {th }}$ YAP which failed to show significant differences (Table 1). No significant differences were noticed between 'Hernandina' and 'Clemenules' in this respect. On the other hand, the tree spread responded 


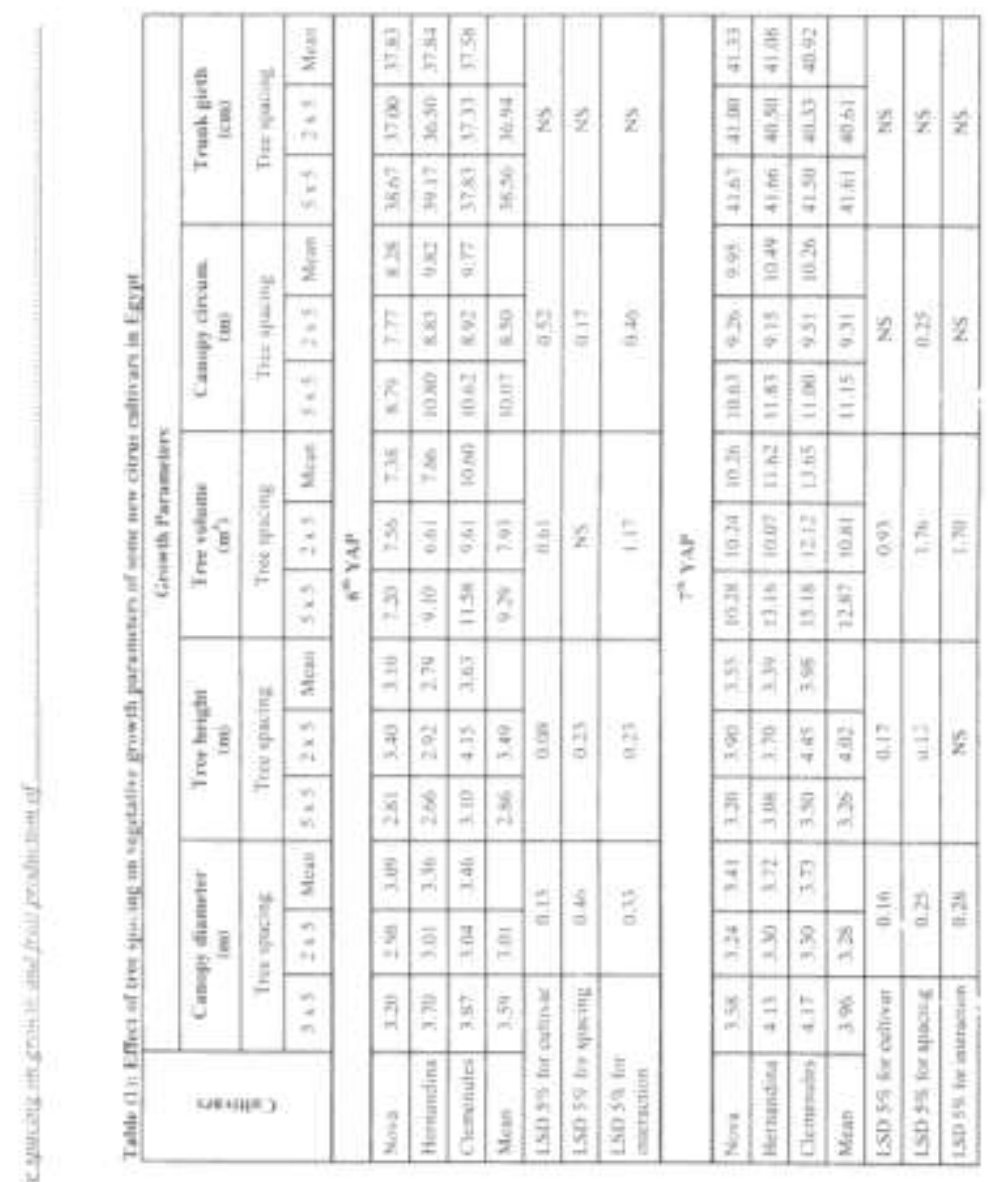


positively to tree spacing, whereas the trees planted at $5 \times 5 \mathrm{~m}$ showed canopy diameter and circumference significantly higher than those planted at $2 \times 5 \mathrm{~m}$ in the $6^{\text {th }}$ and $7^{\text {th }} \mathrm{YAP}$, probably due to the wider space between the trees in the row, and the trees in close spacing filled their allotted spaces early.

The interaction between the cultivars and tree spacing was significant in both seasons for canopy diameter, where trees of 'Hernandina' and 'Clemenules' in the wide spacing had higher diameter than those of 'Nova', while in the close spacing no significant differences were found among the three cultivars.

In this respect, results over 8 years of RongFu (1997) on 'Ponggan' mandarin indicated that the canopy of trees in wide spacing was larger than those in close one, while Nasir et al. (2006) found that grapefruit tree spread did not respond to planting distance. On the contrary, Stuchi et al. (2003) reported that trees of 'Tahiti' lime planted in the $4 \times 1 \mathrm{~m}$ planting space had greater canopy diameters than those planted with other planting spaces ( $4 \times 1.5 \mathrm{~m}, 4 \times 2 \mathrm{~m}$ and $4 \times 2.5 \mathrm{~m})$.

3.1.2. Tree height: For $6^{\text {th }}$ and $7^{\text {th }}$ YAP, 'Clemenules' trees were significantly higher than those of 'Hernandina' and 'Nova' (Table 1). In the $6^{\text {th }}$ YAP, the trees of 'Hernandina' were significantly shorter than those of 'Nova', but had statistically equal height in the $7^{\text {th }}$ YAP.

Tree height was significantly affected by planting density, where trees planted at $2 \times 5 \mathrm{~m}$ were significantly higher than those planted at $5 \mathrm{x}$ $5 \mathrm{~m}$ in both seasons of this study; this was perhaps due to light competition and less space for spreading.

The interaction of tree spacing $\mathrm{x}$ cultivars was significant in the $6^{\text {th }}$ YAP only, whereas trees of 'Clemenules' in the close spacing were the highest, while those of 'Hernandina' in the wide spacing were the shorter.

The present results fully support the finding of Nasir et al. (2006), who observed that grapefruit trees closely planted $(3.5 \times 3.5 \mathrm{~m})$ were higher than those in wider spacing $(7 \times 3.5 \mathrm{~m}$ and $7 \times 7$ $\mathrm{m})$, while Stuchi et al. (2003) stated that the tree height of 'Tahiti' lime was not affected by the planting spaces.

3.1.3. Tree volume: Trees of 'Clemenules' had significantly higher volume as compared with those of 'Hernandina' and 'Nova' in the $6^{\text {th }}$ and $7^{\text {th }}$ YAP (Table 1). On the other hand, trees of 'Hernandina' showed higher volume than those of 'Nova' in the $7^{\text {th }}$ YAP, but in the $6^{\text {th }}$ YAP, both had statistically equal volume.
Trees planted at $5 \times 5 \mathrm{~m}$ were larger in volume than those planted at $2 \times 5 \mathrm{~m}$ in both seasons, although the differences in the $6^{\text {th }}$ YAP failed to attain significance. On the other hand, when the total canopy volume per feddan was calculated, close plantation was the highest due to the higher number of trees per feddan, indicating that the bearing volume was also higher, because when trees are small or in a narrow hedgerow, the total canopy volume may be considered to be productive (Parsons and Wheaton, 2006).

The interaction of tree spacing $\mathrm{x}$ cultivars for tree volume was significant in both seasons due to different response of each cultivar to the tree spacing. Trees of 'Nova' mandarin was not affected by the tree spacing in both seasons, while those of 'Clemenules' and 'Hernandina' were positively affected by the planting spaces.

These results are in harmony with those of Rodríguez et al. (2004), who found that citrus tree growth was lower at short distances in comparison with greater planting distances. On the contrary, Intrigliolo et al. (1994) mentioned that 'Valencia' orange trees planted at closer spacing $(5 \times 3 \mathrm{~m})$ gave the largest canopy, compared with the standard spacing of $6 \times 4 \mathrm{~m}$.

3.1.4. Trunk girth: All cultivars had statistically similar trunk girth in the $6^{\text {th }}$ and $7^{\text {th }}$ YAP. Also, the tree trunk girth was not affected by tree spacing. The non significant effect of tree spacing on the trunk diameter indicated that the competition among trees at the closer spacing was nil until $7^{\text {th }}$ YAP. According to Whitney et al. (1991), water use and root concentration per unit of land area for 7- and 8-year-old trees were similar for the lowest and highest tree densities. These results are in contrast with the finding of Nasir et al. (2006) on grapefruit, who reported that stem girth in the $4^{\text {th }}$ YAP did not respond to tree spacing, but at $5^{\text {th }}$ and $6^{\text {th }}$ YAP it increased with increasing the tree spacing. On the other hand, Wheaton et al. (1995a) mentioned that trunk diameter of 'Valencia' and 'Hamlin' oranges on Milam rootstock was smaller with increasing tree density.

\subsection{Fruit yield}

\subsubsection{Fruit yield per tree:}

Generally, yield increased rapidly during the first four seasons of production, but declined during the $5^{\text {th }}$ one $\left(7^{\text {th }}\right.$ YAP). Largest yields were obtained during $4^{\text {th }}$ season when trees were 6 year old (Table 2).

'Hernandina' trees significantly produced higher yields in the $3^{\text {rd }}$ and $4^{\text {th }}$ YAP as compared with those of 'Clemenules' and 'Nova' cultivars; this means that trees of 'Hernandina' were 


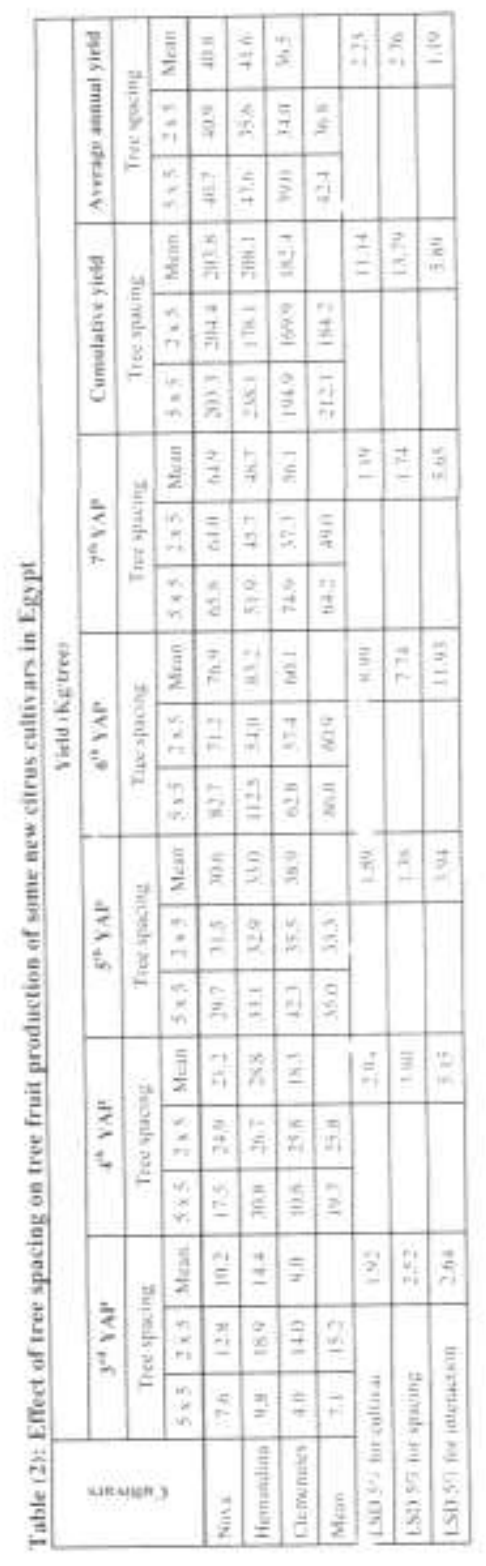


introduced in production early. 'Clemenules' trees showed the highest yield in the $5^{\text {th }}$ YAP only, and 'Nova' trees had the highest yield in the $7^{\text {th }}$ YAP, while in $6^{\text {th }}$ one were statistically similar to those of 'Hernandina', which produced the highest yield. On the other hand, 'Nova' and 'Clemenules' trees were somewhat regular in production; while 'Hernandina' trees showed alternate bearing, especially in the $7^{\text {th }}$ YAP.

Closely spaced $(2 \times 5 \mathrm{~m})$ trees significantly produced higher yield in the $3^{\text {rd }}$ and $4^{\text {th }}$ YAP. Their fruit yield was $114 \%$ and $27 \%$ greater than those wide spaced $(5 \times 5 \mathrm{~m})$ trees, in both seasons, respectively. This is probably because the trees in close spacing developed bearing volume more rapidly (Parsons and Wheaton, 2006). In addition, Wheaton et al. (1991) reported that many citrus scion/stock combinations will develop a canopy of $2 \mathrm{~m}$ in diameter and $2.5 \mathrm{~m}$ high through $3-5$ years. With trees of these dimensions, the entire canopy theoretically should be bearing volume. Starting from $5^{\text {th }}$ YAP to $7^{\text {th }}$ YAP the attitude was inverted, where the trees in the wide spacing $(5 \mathrm{x}$ $5 \mathrm{~m})$ produced significantly higher yields; about $5 \%, 41 \%$ and $31 \%$ over those in closer planting in the three seasons, respectively.

These results are in harmony with those obtained by RongFu (1997) on 'Ponggan' mandarin, who observed that the yields for the closely spaced trees were higher in the first 2 bearing years than that for the wider spacing, but from the fifth year of bearing the yield was higher for the wider spacing. In addition, Tribulato et al. (1994) stated that 'Navelina' orange at 1200 trees/ha (504 trees/feddan) produced the same yield/tree as those planted at 416 trees/ha (175 trees/feddan) in the first 3 years, but from 6 years onwards yield was reduced due to the trees competition. However Intrigliolo et al. (1994) reported that the mean yield/tree of 'Valencia' orange was higher in trees at the closer spacing (5 x $3 \mathrm{~m}$ ). On the contrary, Rodríguez et al. (2004) found that citrus tree production was lower at short distances in comparison with greater planting distances, and Nasir et al. (2006) mentioned that trees of grapefruit in wider spacing $(7 \times 7 \mathrm{~m})$ produced higher yields during the first 3 years of production than those in the close spacing (7 x 3.5 and $3.5 \times 3.5 \mathrm{~m})$.

Cumulative yield for 5 years and the average annual yield/tree were significantly lower for 'Clemenules' cultivar as compared with 'Nova' and 'Hernandina' cultivars, which were statistically similar in this respect (Table 2). On the other hand, trees planted at $5 \times 5 \mathrm{~m}$ had significantly higher cumulative and average annual yield/tree (about 15\% greater than those planted at $2 \times 5 \mathrm{~m}$ ). On the contrary, Intrigliolo et al. (1994) reported that 'Valencia' orange trees planted at $5 \times 3 \mathrm{~m}$ spacing gave the highest cumulative yield/tree as compared with other spacing $(6 \times 4,6 \times 4 \times 2$ and $5 \times 2.5 \mathrm{~m}$ ).

The interaction of tree spacing $\mathrm{x}$ cultivars was significant for fruit yield in all seasons and for the cumulative and the average annual yield/tree. 'Nova' mandarin was not affected by the tree spacing starting from the $5^{\text {th }}$ YAP, whereas the annual fruit production and the cumulative yield per tree were statistically equal in both spacing (Table 2). On the contrary, 'Clemenules' and 'Hernandina' cultivars were more affected by the tree spacing, where the cumulative yield/tree in the wide spacing was significantly higher than that in the close spacing, for both cultivars. The trees of 'Hernandina' clementine in the wide spacing had the highest cumulative yield per tree (283.1 $\mathrm{kg} /$ tree), while the lowest one was showed by 'Clemenules' trees in the close spacing (169.9 $\mathrm{kg} /$ tree).

\subsubsection{Fruit yield per feddan:}

Fruit production per feddan had the same trend of fruit production per tree for all cultivars because the production per feddan depends on the tree yield (Table 3 ).

The production per feddan increased gradually during the first four years, regardless of the tree spacing, and the highest yield was obtained in the forth year when trees were 6-year-old (24.3 and 13.8 ton/feddan in the close and wide spacing, respectively), then decreased in the next year, may be due to the alternate bearing. Wheaton et al. (1991) reported that yield of citrus trees in high density planting $(1.5 \times 3.3 \mathrm{~m})$ increased rapidly during the first three seasons but was reduced during the $4^{\text {th }}$ year and the largest yields were obtained when trees were 7 -years-old.

Trees planted at $2 \times 15 \mathrm{~m}$ produced significantly higher yields per feddan through the first five years of production as compared with those planted at $5 \times 5 \mathrm{~m}$. In the first season of production ( $3^{\text {rd }} \mathrm{YAP}$ ), the yield from higher density planting was about $454 \%$ greater than that from lower density. The difference in production between the two planting densities was decreased with tree age, whereas the increment in production in the closely planted trees was about $221 \%$, $137 \%, 76 \%$ and $90 \%$ in $4^{\text {th }}, 5^{\text {th }}, 6^{\text {th }}$ and $7^{\text {th }}$ YAP, respectively. This productivity increment in the closely planting was a result of the higher number 

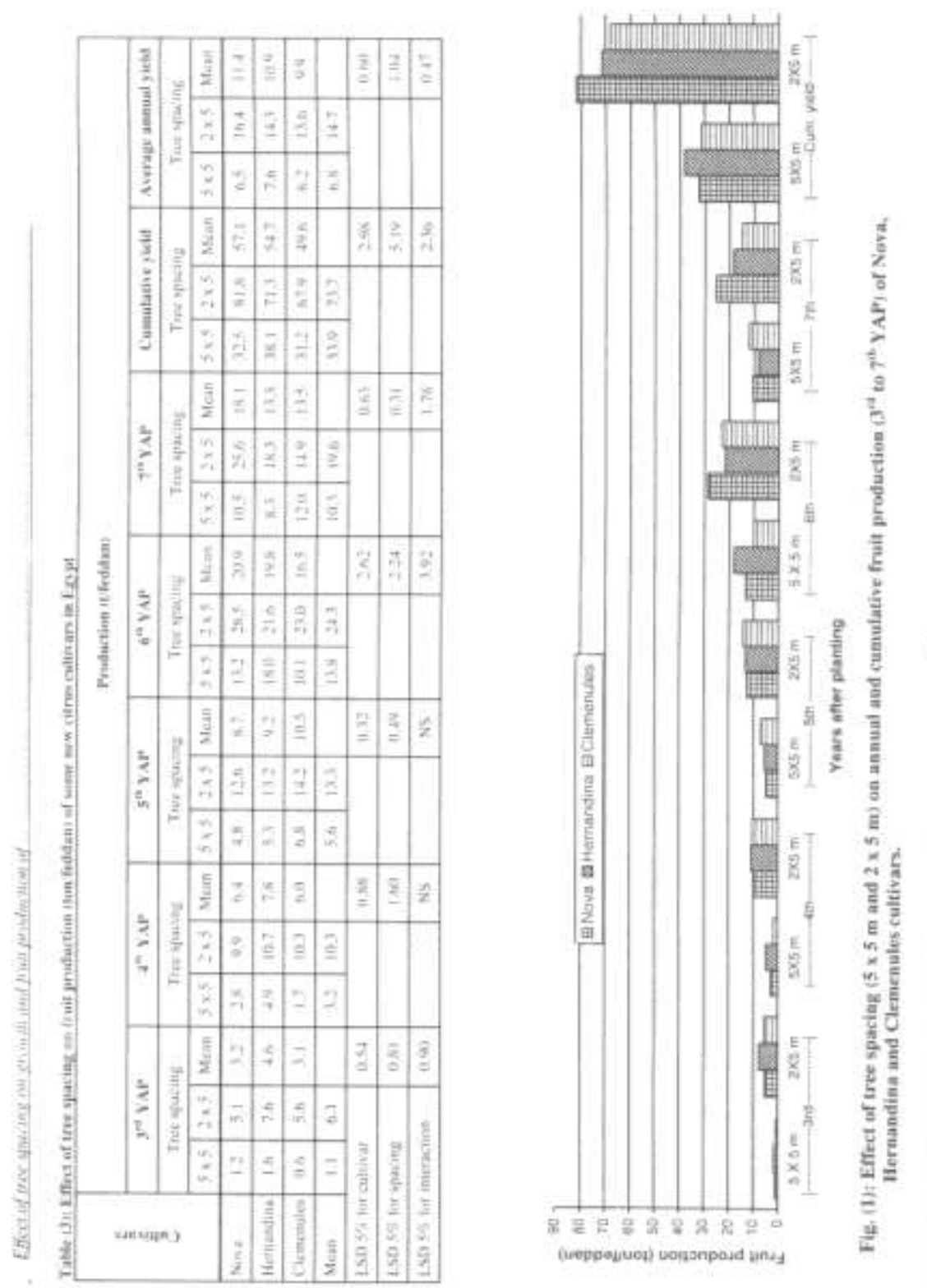
of trees per feddan (higher canopy volume, otherwise bearing volumes).

This trend is in accordance with the finding of Gallasch (1983) on 'Washington Navel' orange, who mentioned that at six years, the yield/ha from closely planted trees was $121 \%$ greater than from widely spaced. Also, Whitney et al. (1991) found that fruit yields/ha of 'Hamlin' orange were greater for the $4.5 \times 2.5 \mathrm{~m}$ spacing in the early years; were comparable for both spacing during the $7^{\text {th }}$ and $8^{\text {th }}$ YAP, and favored the $6 \times 4.5 \mathrm{~m}$ spacing in the $9^{\text {th }}$ year. In addition, Intrigliolo et al. (1994) showed that 'Valencia' orange trees in closer planting $(5 \mathrm{x}$ $2.5 \mathrm{~m})$ produced a $123 \%$ increase in yield/ha compared with standard spacing. On the other hand, Rodríguez et al. (2004) reported that the yield of citrus trees was increased proportionally to the increase in the number of trees per unit of area during the first years, and later went similar or superior to those obtained at shorter distances.

Cumulative yield per feddan for first 5 years of production (tree age 3 to 7 years) from trees planted at $2 \times 5 \mathrm{~m}$ was about $40 \mathrm{t}(117 \%)$ more than that from those planted at $5 \times 5 \mathrm{~m}$. Average annual yield per feddan (Table 3 ) reached to 14.7 $\mathrm{t} /$ feddan in closely planted trees, about $8 \mathrm{t}$ over that in widely spaced trees annually.

On the other hand, the interaction of tree spacing $\mathrm{x}$ cultivars was significant for fruit production per feddan in the $3^{r d}, 5^{\text {th }}$ and $7^{\text {th }}$ YAP and for the cumulative and the average annual yield/feddan. The response of the cultivars to planting spacing were different, where data of the cumulative yield/feddan indicated that 'Nova' mandarin was the most excellent in the narrow spacing, while 'Hernandina' was the best in the wide spacing, and 'Clemenules' had the lowest cumulative yield/feddan (Fig 1).

Tribulato et al. (1994) found that the cumulative yield of 'Navelina' orange after 13 years in high-density planting was $71 \%$ over that in normal density (416 trees/ha; or 175 trees/feddan), also 'Tarocco' orange in highdensity planting (832 trees/ha; or 349 trees/feddan) after 5 years produced $36 \%$ higher yield than that in normal density (416 trees/ha), while for lemons, cumulative yield over 4 years from high-density planting was $115 \%$ higher than from normal density. Also, average annual yield (t/ha) for the first 5 years of production increased substantially with increasing tree density (Wheaton et al., 1995a, on oranges). In addition, Stuchi et al. (2003) found that average fruit yield/ha of 'Tahiti' lime trees over 3 years in close space planting was $65 \%$ greater than those in wider space planting.

\section{Conclusions:}

The growers look for earlier net returns on their investment. The obtained results in this study showed that the trees planted at $2 \times 5$ m produced from 5 to $10.5 \mathrm{t}$ per feddan annually greater than those planted at $5 \times 5 \mathrm{~m}$ through 7 years. This productivity increment in the closely planting was due to the higher trees number per feddan (higher canopy volume, otherwise bearing volumes). This means that the growers can obtain about $117 \%$ annually over economic return from the same land area with, approximately the same cost of production.

On the other hand, 'Clemenules', 'Hernandina' and 'Nova', as new citrus cultivars in Egypt performed satisfactory in a high-density planting $(2 \times 5 \mathrm{~m})$ through 7 year after planting, despite of 'Nova' mandarin was the most excellent followed by 'Hernandina' and 'Clemenules' (cumulative yields were 82, 71 and $68 \mathrm{t} /$ feddan, for the three cultivars, respectively); and could continue until the productivity per feddan decrease compared to normal spacing.

\section{REFERENCES}

Bassal M.A. (2001). A comparative study between some new citrus cultivars in Egypt. Anal. Agric. Sci., Moshtohor. 39(2): 1165-1182.

Bassal M.A. (2009). Growth, yield and fruit quality of 'Marisol' clementine grown on four rootstocks in Egypt. Scientia Horticulturae. 119 (2): 132-137.

Gallasch P.T. (1983). Effects of planting distances on production by 'Washington Navel' orange. Australian Journal of Experimental Agriculture and Animal Husbandry. 23(123): 437-440.

Intrigliolo F., Recupero R.G. and Giuffrida A. (1994). Effect of planting density and rootstock on performance of Valencia orange. Proc. Intel. Soc. Citriculture. $7^{\text {th }}$ Congress, Catania, Italy, March 8-13, 1992, Publ. 1994 .Vol. 2: 705-708. (C.F. CAB Abst., AS: 19950309610).

M-STAT (1990). A Microcomputer Program for the Design, Management and Analysis of Agronomic Research Experiments. Michigan State University.

Nasir M.A., Abdul-Aziz, Mohar T.A., Rehman M.A. and Saeed A. (2006). Effect of planting distance on tree growth and fruit quality of 'Shamber' grapefruit under agro climatic 
conditions of Sargodha. J. Agric. Res., Pakistan. 44(4): 353-358.

Parsons L.R. and Wheaton T.A. (2006). Tree density, hedging, and topping. Institute of food and Agricultural Sciences, University of Florida, Fact Sheet HS-1026 pp. 4. (http://edis.ifas.ufl.edu.)

QingSheng T. and ShinXian T. (2002). Experiment summary of early high production of Navel orange growth in the mountainous region of Hunan province. South China Fruits. 31(6): 11-12. (C.F. CAB Abst., AS:20033058821).

Rodríguez R., del Valle N., Aranguren M., García M.E., Pérez R., Rodríguez K. and Rodríguez J. (2004). Planting distances for citrus in red ferralitic soils of Jagüey Grande, Matanzas, Cuba. Acta Hort. (ISHS) 632: 213-218. (Abst.,http://www.actahort.org/books/632/632 27.htm).

RongFu H. (1997). Study on the effect of planting density on the growth and production of Ponggan mandarin. South China Fruits. 26(5): 21. (C.F. CAB Abst., AS: 199980306391).

Steel R.G.D., Torrie J.H. and Diskey D.A. (1997). Principles and Procedures of Statistics. A Biometrical Approach $3^{\text {rd }}$ ed. McGraw-Hill Publishing Company, p. 336-376, New York. USA.

Stuchi E.S., Donadio L.C. and Sempionato O.R. (2003). Performance of 'Tahiti' lime on Poncirus Trifiliata var. Monostrosa Flying Dragon in four densities. Fruits. 58: 13-17.

Tribulato E., Continella G. and Rosa G. (1994). Research on higher density planting for orange and lemon. Proc. Intel. Soc.
Citriculture. $7^{\text {th }}$ Congress, Catania, Italy, March 8-13, 1992, Publ. 1994, vol. 2: 702704. (C.F. CAB Abst., AS: 19950309609).

Tucker D.P.H., Wheaton T.A. and Muraro R.P. (1994). Citrus tree spacing. Institute of food and Agricultural Sciences, University of Florida, Fact Sheet HS-143 pp. 11.

Wheaton T.A., Castle W.S., Whitney J.D. and Tucker D.P.H. (1991). Performance of citrus scion cultivars and rootstocks in high-density planting. HortScience. 26(7): 837-840.

Wheaton T.A., Whitney J.D., Castle W.S., Muraro R.P., Browning H.W. and Tucker D.P.H. (1995a). Citrus scion and rootstock, topping height, and tree spacing affect tree size, yield, fruit quality, and economic return. J. Amer. Soc. Hort. Sci. 120(5): 861-870.

Wheaton T.A., Whitney J.D., Castle W.S., Muraro R.P., Browning H.W. and Tucker D.P.H. (1995b). Tree vigor important in citrus tree spacing and topping. Proc. Fla. State Hort. Soc. 108: 63-69.

Whitney J.D., Elezaby A., Castle W.S., Wheaton T.A. and Littell R.C. (1991). Citrus tree spacing effects on soil water use, root density, and fruit yield. American Society of Agricultural Engineers. 34(1): 129-134.

Wutscher H.K. (1995). Performance of 'Hamlin' orange on 16 rootstocks in east-central Florida. HortScience. 30(1): 41-43.

Xian X.C., Huang S.R., Ma P.Q., Wu W., Liang W.Y. and Li S.U. (1994). Techniques for producing high yields of good quality cv. Ponggan fruits. China Citrus. 23(1): 19-20. (C.F. CAB Abst., AS: 19950312971).

$$
\begin{aligned}
& \text { تأثير مسافات الزراعة على نمو وإثمار بعض أصناف الموالح الجديدة في مصر } \\
& \text { مجدي على بصل } \\
& \text { قسم البساتين - كلية الزراعة ـ جامعة قناة السويس ـ الإسماعيلية ـ مصر } \\
& \text { ملخص خادي }
\end{aligned}
$$

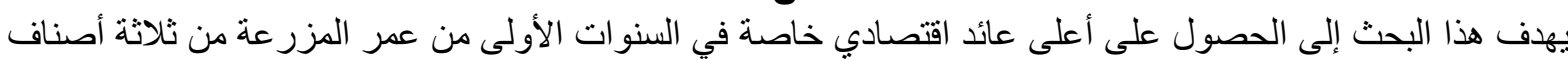

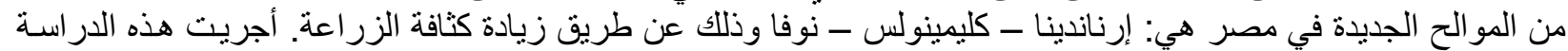

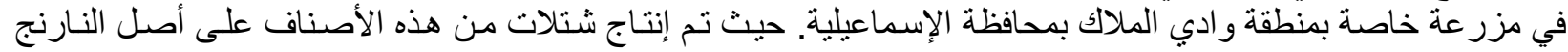

$$
\begin{aligned}
& \text { تحت الصوب. } \\
& \text { في أكتوبر } 1999 \text { نم زر اعة شتلات متجانسة عمر سنة من هذه الأصناف في الأرض المستديمة على مسافتي زر اعـة همـا }
\end{aligned}
$$

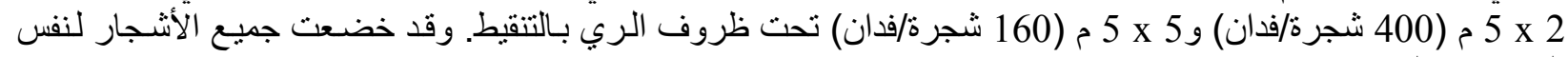

$$
\begin{aligned}
& \text { المعاملات الزر اعية. }
\end{aligned}
$$


بدءأًًَ من السنة الثالثة وحتى السنة السابعة بعد الزر اعة (2003/2002 - 2007/2006) تم تقدير محصول الأشـار

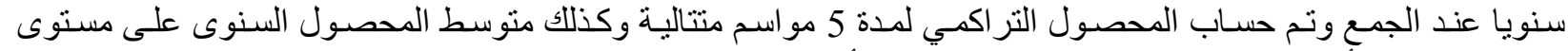

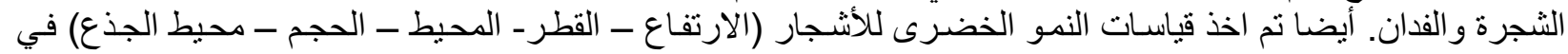

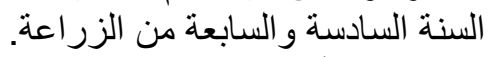
وكانت أهم النتائج المتحصل من النقل عليها ما يلي:

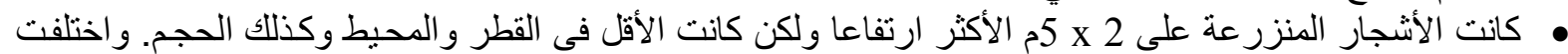

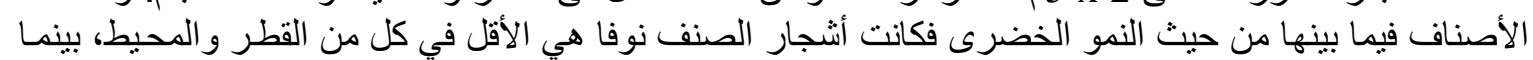

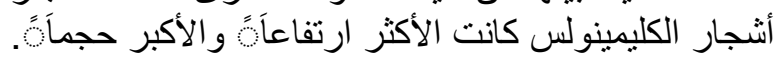

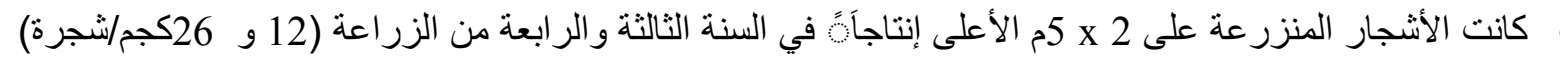

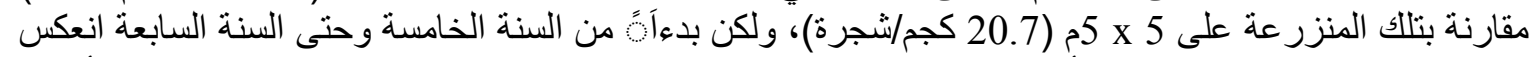

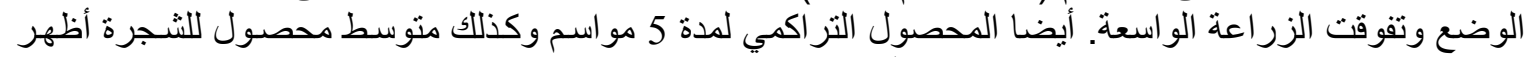

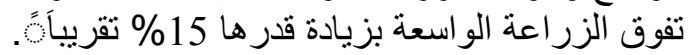

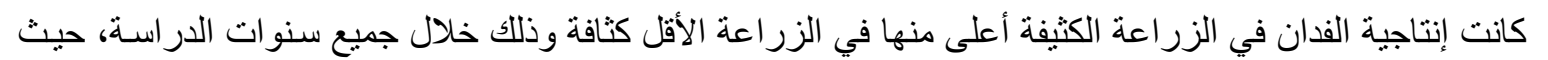

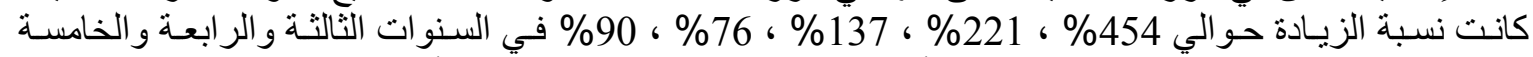

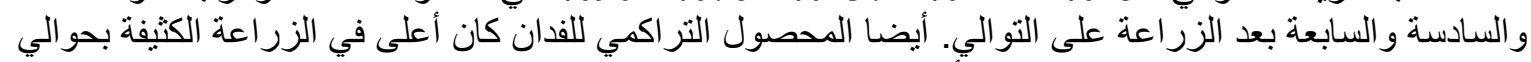

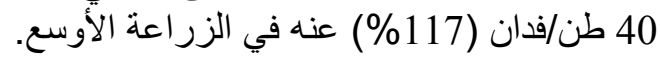

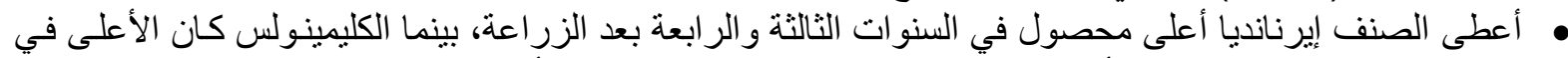

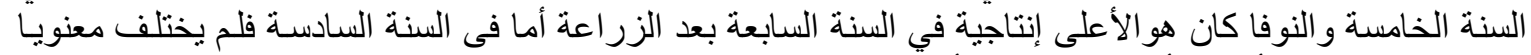

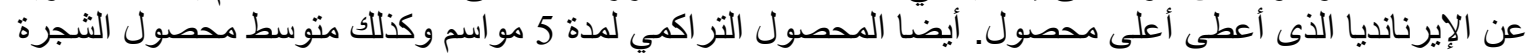

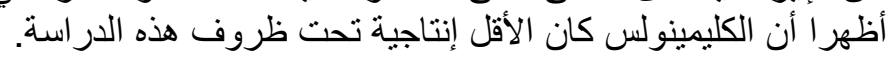

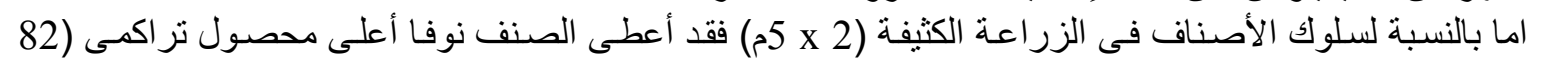

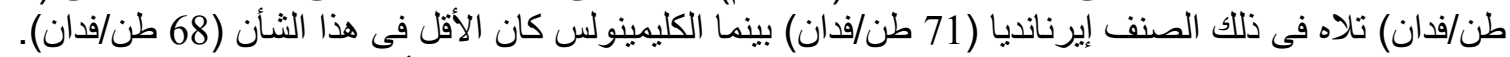

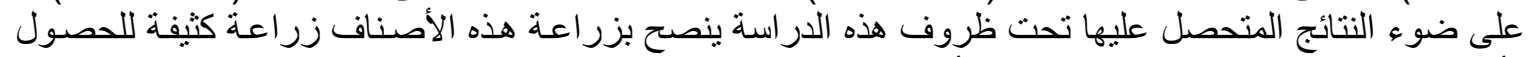

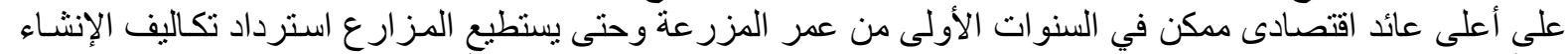

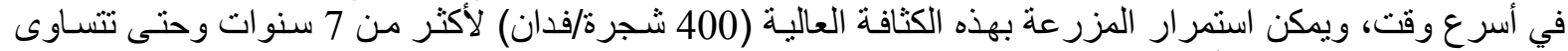
إنتاجية الفدان مع الكثافة الأقل.

المجلة العلمية لكلية الزراعة - جامعة القاهرة - المجلا (60) العدد الثانى (أبريل 2009) : 178-187. 